\title{
Appraisal of Imaging Requests and Findings from MRI Scans of Patients at State Specialists Hospital Bauchi
}

1 Prince Ameh Ogenyi

2 Andrew England

1 Joseph Dlama

3 Fati Malgwi

1 Mohammed Umar

3 Moi Silas

4 Samuel Shem

1 Ginikanwa Njoku

1 Radiology Department, Abubakar Tafawa Balewa University Teaching Hospital Bauchi, Nigeria.

2 Directorate of Radiography, University of Salford, Manchester, United Kingdom.

3 Department of Radiography, University of Maiduguri, Borno, Nigeria.

4 Radiology Department, State Specialist Hospital Gombe, Nigeria.

\section{Abstract}

Background: MRI plays a vital role in diagnosis of diseases.

Objectives: To determine the pattern of imaging requests and findings from MRI scans of patients in the Bauchi State Hospital.

Methods: A prospective cross-sectional study of MRI request forms and findings of 138 patients was conducted from August 2016 to January 2017. MRI scans were performed using a $0.35 \mathrm{~T}$ Neusoft MRI scanner and reported by a group of consultant radiologists. Data were analysed using descriptive statistics with the computer software SPSS version 22 (IBM, New York, USA).
Results: This study revealed that majority of the MRI requests were for lumbosacral spine examinations $(n=84$, $60.9 \%$ ), followed closely by MRI of the brain ( $n=42,30.4 \%)$ and thirdly shoulder and abdomen examinations with a frequency of $4.3 \%$ each. Out of $138 \mathrm{MRI}$ scans studied, intervertebral disc prolapse ( $n=60,43.5 \%)$ was the commonest finding from MRI scans of patients, the second most prevalent finding was L4-L5 degenerative disc disease ( $n=12,8.7 \%)$. Intramuscular lipoma and basal ganglia edema had a prevalence of $4.3 \%$.

Conclusion: The commonest requests were MRI lumbosacral and, in terms of findings, we found intervertebral disc prolapse, L4-L5 degenerative disc disease, basal ganglia edema and intramuscular lipoma as the major findings from MRI scans in Bauchi.

Keywords: basal ganglia, disc prolapse, metastasis, lipoma

Article received: 29.12.2017.

Article accepted: 15.03 .2018 .

DOI: $10.24141 / 1 / 4 / 1 / 10$

Author for correspondence:

Prince Ameh Ogenyi, Radiology Department, Abubakar Tafawa Balewa University Teaching Hospital, Bauchi email: jacobameh3@gmail.com, phone number: $+2347061371401$ 


\section{INTRODUCTION}

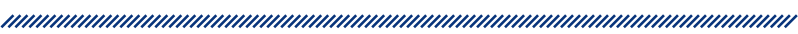

The emergence of Magnetic Resonance Imaging (MRI) as an imaging modality could be credited to four major scholars: Nikola Tesla, who discovered the rotating magnetic field in 1882; Professor Isidor Rabi, who conceptualized the quantum phenomenon dubbed Nuclear Magnetic Resonance (NMR) in 1937; Paul Lauterbur, who produced the first NMR image in 1973 at the State University of New York at Stony Brook, and Professor Raymond Damadian, who produced the first scan after creating the first whole-body MRI scanner in $1977^{[1-3] \text {. }}$

MRI is a non-invasive, non-ionising imaging modality used to diagnose and treat medical conditions ${ }^{[1]}$. It uses a powerful magnetic field and radiofrequency waves to construct multiplanar images of the body which are then displayed on a computer monitor ${ }^{[2-5]}$.

Since the creation of the first MRI image in 1977, significant advances have been recorded in medical imaging leading to the creation of highly sophisticated MRI machines which produce high quality images used to detect and confirm the presence of certain pathologies which are not easily diagnosed using conventional Xray imaging and other imaging modalities ${ }^{[5]}$. Despite the cost of MRI, its safety profile and the ability to provide accurate soft tissue details make it highly indispensable to medicine. A recent study by Griffiths et al. clearly demonstrated the extended clinical value of MRI in diagnosis of fetal brain abnormalities ${ }^{[6]}$.

At the Radiology Department of the Specialist Hospital Bauchi, the demand for MRI scans remains high because this centre is the only hospital providing MRI imaging services in the state. Even though there are numerous hospitals providing medical services in the state, most of these hospitals cannot afford the high costs of the MRI machines. It is important to document referral patterns and imaging findings in the state in order to identify prevailing health challenges of residents. Hence, the aim of this study was to determine the pattern of requests for MRI scans and findings from a smallscale feasibility sample at the State Specialist Hospital.

\section{MATERIALS AND METHODS}

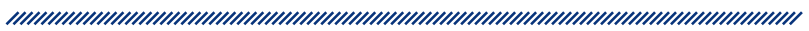

Ethical clearance was obtained from the hospital Research Ethics Committee and a prospective crosssectional study of MRI requests and findings from 138 MRI scans was conducted. Informed consents were obtained from all patients who were involved in this study.

The study was conducted across a period of six months (August 2016 - January 2017). The procedures were carried out in the MRI Unit of the State Specialist Hospital Bauchi, Nigeria, using an open bore MRI scanner (0.35T Neusoft MRI Machine). Multiplanar images were acquired using turbo-spin echo (T1WS: TR/TE 450-550/1522ms; T2WS:4000-5000/100-125ms), slice thickness $4 \mathrm{~mm}$, no slice gap, field of view- sagittal $300 \mathrm{~mm}$, axial $250 \mathrm{~mm}$, image matrix $192 \times 256$ or $256 \times 256$.

MRI Sequences

T1 weighted

plane: sagittal (or volumetric 3D)

sequence: fast-spin echo (T1 FSE) or gradient

(T1 MPRAGE)

T2 weighted

plane: axial

sequence: T2 FSE

FLAIR

plane: axial

sequence: FLAIR

Diffusion weighted imaging (DWI)

plane: axial

sequence: $D W I: B=0, B=1000$ and $A D C$

\section{Susceptibility weighted imaging (SWI)}

plane: axial

sequence: susceptibility weighted imag-

ing (ideal) or T2*

MRI coils for the respective body part were utilized for the examination.

The request forms for MRI scans were reviewed and the clinical information which included age, sex and provisional diagnosis provided by the referrer was captured. All MRI reports were performed by a team of 3 consultant radiologists. Data was analysed using Statistical Package for Social Sciences (SPSS) version 22.0 (IBM, New York, USA). 


\section{RESULTS}

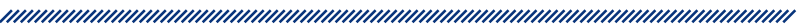

Of the 138 patients included in the study, $52 \%$ were females. Age range for the study sample was 11-70 years with a mean (SD) of 43.8 (14.9) years. The majority of the respondents were within the 51-60 years of age group (48, 35\%), followed by $41-50$ years $(30,21.7 \%)$ and then 21-30 years $(24,17 \%)$.Table 1 shows the pattern of MRI requests. MRI scans of the lumbosacral spine were the most frequent ( $n=84,60.9 \%)$, followed by brain ( $n=42,30.4 \%$ ) and then, shoulder and abdomen (with frequencies of 6 [4.3\%] each). Table 2 provides details of the common clinical indications for MRI scans. Lower back pain was the commonest indication ( $n=42,30.4 \%)$, followed by lumbar spondylosis ( $n=18,13 \%)$ and Pott's disease $(n=12,8.7 \%)$.

Table 3 illustrates the pattern of MRI findings. Intervertebral disc prolapse $(n=60,43.5 \%)$ was the commonest finding, followed by L4-L5 degenerative disc disease $(\mathrm{n}=12,8.7 \%)$ and then, Intramuscular lipoma $(\mathrm{n}=6$, $4.3 \%)$ and basal ganglia edema $(n=6,4.3 \%)$. The pattern of findings in relation to gender showed that both sexes were evenly affected by intervertebral disc prolapse (50\% females, 50\% males). More females were affected by intramuscular lipoma and basal ganglia edema $(n=6$, $100 \%$ ), while their male counterparts suffered more from multiple sclerosis and spinal metastasis $(n=6$, 100\%) (Table 4).

Table 5 demonstrates the pattern of findings in relation to age. It shows that $90 \%$ of patients with intervertebral disc prolapse were within the 41-60 years of age group, $100 \%$ of the patients with L4-L5 degenerative disc disease were within the $41-50$ years of age group and $71 \%$ of the patients with normal MRI scan were within the 11-40 years of age group.

\begin{tabular}{|c|c|c|}
\hline & Table 1. Pattern of MRI Requests \\
\hline MRI Projections & Frequency & Percentage \\
\hline MRI Lumbosacral & 84 & 60.9 \\
\hline MRI Brain & 42 & 30.4 \\
\hline MRI Shoulder & 6 & 4.3 \\
\hline MRI Abdomen & 6 & 4.3 \\
\hline Total & 138 & 100.0 \\
\hline
\end{tabular}

\begin{tabular}{|c|c|c|}
\hline & Table 2. Reasons for Referral & \\
\hline Indication for MRI Scan & Frequency & Percentage \\
\hline Lower Back Pain & 42 & 30.4 \\
\hline ? Lumbar spondylosis & 18 & 13.0 \\
\hline ? Potts disease & 12 & 8.7 \\
\hline ? Metastasis & 12 & 8.7 \\
\hline Intramuscular pain & 6 & 4.3 \\
\hline Recurrent headache & 6 & 4.3 \\
\hline Seizure disorder & 6 & 4.3 \\
\hline ? Brain tumour & 6 & 4.3 \\
\hline ? Disc prolapse & 6 & 4.3 \\
\hline Recurrent drop attack & 6 & 4.3 \\
\hline Hemiparesis & 6 & 4.3 \\
\hline Vascular dementia & 6 & 4.3 \\
\hline RTA & 6 & 4.3 \\
\hline Total & 138 & 100.0 \\
\hline
\end{tabular}




\begin{tabular}{|c|c|c|}
\hline \multicolumn{2}{|c|}{ Table 3. Pattern of MRI Findings } \\
\hline MRI Findings & Frequency & Percentage \\
\hline Intervertebral disc prolapse & 60 & 43.5 \\
\hline Normal & 42 & 30.4 \\
\hline L4-L5 degenerative disc disease & 12 & 8.7 \\
\hline Intramuscular lipoma & 6 & 4.3 \\
\hline Basal ganglia edema & 6 & 4.3 \\
\hline Multiple sclerosis & 6 & 4.3 \\
\hline Spine metastasis & 6 & 4.3 \\
\hline Total & 138 & 100.0 \\
\hline
\end{tabular}

\begin{tabular}{|c|c|c|c|c|}
\hline \multicolumn{5}{|c|}{ Table 4. Findings in Relation to Gender } \\
\hline Findings & Male & Female & Total \\
\hline Intervertebral disc prolapse & 30 & 30 & 60 \\
\hline Normal & 18 & 24 & 62 \\
\hline Intramuscular lipoma & 0 & 6 & 6 \\
\hline Basal ganglia edema & 0 & 6 & 6 \\
\hline Multiple sclerosis & 6 & 0 & 6 \\
\hline Spine metastasis & 6 & 0 & 6 \\
\hline L4-L5 degenerative disc disease & 6 & 6 & 12 \\
\hline Total & 66 & 72 & 138 \\
\hline
\end{tabular}

\begin{tabular}{|c|c|c|c|c|c|c|c|c|}
\hline \multicolumn{8}{|c|}{ Table 5. Pattern of MRI Findings in Relation to Age } \\
\hline $\begin{array}{c}\text { Age } \\
\text { Group }\end{array}$ & $\begin{array}{c}\text { Intravertebral } \\
\text { disc Prolapse }\end{array}$ & Normal & $\begin{array}{c}\text { Intra- } \\
\text { muscular } \\
\text { Lipoma }\end{array}$ & $\begin{array}{c}\text { Basal ganglia } \\
\text { Edema }\end{array}$ & $\begin{array}{c}\text { Multiple } \\
\text { sclerosis }\end{array}$ & $\begin{array}{c}\text { Spine } \\
\text { metastasis }\end{array}$ & $\begin{array}{c}\text { L4-L5 Disc } \\
\text { Disease }\end{array}$ \\
$\begin{array}{c}\text { Total } \\
\text { I1-20 }\end{array}$ & 0 & 12 & 0 & 0 & 0 & 0 & 0 \\
\hline $21-30$ & 0 & 18 & 6 & 0 & 0 & 0 & 0 \\
\hline $31-40$ & 0 & 0 & 0 & 6 & 6 & 0 & 0 \\
\hline $41-50$ & 12 & 0 & 0 & 0 & 0 & 6 & 12 \\
\hline $51-60$ & 42 & 6 & 0 & 0 & 0 & 0 & 12 \\
\hline $61-70$ & 6 & 6 & 0 & 0 & 0 & 0 & 0 \\
\hline Total & 60 & 42 & 6 & 6 & 6 & 6 & 0 \\
\hline
\end{tabular}

\section{DISCUSSION}

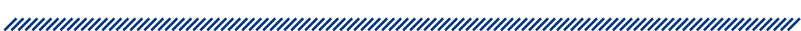

Understanding findings from MRI scans is vital for confirming diagnosis and the preparation of treatment plans for different diseases. In this study, we found that the commonest MRI requests were for lumbosacral spine examinations $(n=84,60.9 \%)$, followed closely by MRI of the brain $(n=42,30.4 \%)$ and thirdly shoulder and abdomen examinations with a frequency of $4.3 \%$ each.
These results prove that, in our environment, MRI is mainly used for ascertaining lumbosacral and brain pathologies and so healthcare providers across the country must ensure that the MRI unit is always functional as this significantly improves patient care and management. While requests for MRI are now common nationwide, it is essential to have clearly specified criteria for the everyday use of MRI for both referring practitioners and radiologists in order to preclude inappropriate use of MRI and leverage on economic outcomes ${ }^{[7]}$. More 
importantly, radiologists should get more involved in the fight against unwarranted studies, even through the use of such expressions as "does not require further inspection", "no clinical significance" among others ${ }^{[8]}$. While studies have been conducted on findings from lumbosacral MRI, there is dearth of empirical evidence globally on the findings from other MRI requests ${ }^{[9-11]}$.

With regards to the gender distribution of patients in this study, we found more females $(n=72,52.2 \%)$ presenting for MRI scans.In this study, $60.9 \%$ of the patients $(n=84)$ had to undergo a lumbosacral MRI, and the majority were female ( $n=44,52 \%)$. Previous studies on lumbosacral MRI conducted by Mustapha et al. in Maiduguri, Nigeria (34\% females), Uduma et al. in Cameroun (40\% females) and Irurhe et al., (35\% females) reported fewer females in their respective studies ${ }^{[9,10,11]}$. The reason for having more females present for MRI is likely due to the fact that clinicians knew about the safety of MRI and that women of child-bearing age had no radiation risk while taking MRI scans ${ }^{[6,12]}$. Consequently, more males were referred for $\mathrm{CT}$ scans in view of cost, availability and lesser degree of radiation safety concerns.

The age distribution of patients revealed that 51-60 years of age group had the highest frequency $(n=48$, $34.8 \%$ ), 41-50 years of age group was next, with a frequency of 30 (21.7\%).Previous studies on lumbosacral MRI by Mustapha et al., Irurhe et al., and Younis et al. reported that majority of patients who underwent MRI scans were either in their forties or fifties ${ }^{[9,11,13]}$. In this study, we evaluated MRI lumbosacral scans and found that $70 \%(n=42)$ of patients suffering from intervertebral disc prolapse were in their fifties. This suggests that patients over the age of 40 are more likely to be imaged with MRI scan than those under 40 , and that patients over the age of 40 are more likely to suffer from spinal and brain-related diseases. In terms of significance, these findings suggest that clinicians need not refer patients under 40 for MRI scans, unless this is highly imperative, as well as clinically beneficial. The fact that majority of the patients under $40(71 \%)$ had normal MRI scans further emphasized the need to enhance efficiency of MRI services.In this study, lower back pain $(n=42$, $30.4 \%$ ) was the commonest indication for MRI scans, lumbar spondylosis ( $n=18,13 \%$ ) was the second, and Pott's disease $(n=12,8.7 \%)$ was the third. Lower back pain remains a major problem throughout the world, with the highest prevalence among female individuals and those aged $40-80^{[14,15]}$. Among females, lower back pain could be attributed to pain related to osteoporosis, menstruation, or pregnancy ${ }^{[16-21]}$. Causal dimensions to the prevalence of lower back pain among males in the region may not be unconnected to work-related stress.

The Royal Australian and New Zealand College of Radiologists (RANZCR) generally recommends that MRI reports address the clinical question, provide a diagnosis or differential diagnosis and, where a number of possibilities exist, state them and describe their relative likelihood ${ }^{[22]}$. It is equally imperative to provide a concise, clinically contextualised interpretation of the previously described imaging observations. If findings are normal or non-significant, this should be stated explicitly as well as recommendations for further imaging, investigations, referral or treatment, where relevant ${ }^{[22]}$. In this study, we identified intervertebral disc prolapse $(n=60,43.5 \%)$ as the most prevalent finding. Others findings were normal ( $n=42,30.4 \%)$, L4-L5 disc degeneration ( $n=12,8.7 \%)$, as well as intramuscular lipoma and basal ganglia edema with $4.3 \%$ prevalence. Other studies on findings from lumbosacral MRI findings conducted earlier by Mustapha et al., Uduma et al., Ibe, and Cheung et al., also found intervertebral disc prolapse to be a prevailing health challenge among residents in Maiduguri, Cameroun, South East Nigeria, and Southern China respectively ${ }^{[9,10,23,24]}$. Emphasis on the role MRI plays in diagnosis of spinal diseases remains paramount ${ }^{[25]}$.

Intervertebral disc prolapse also known as disc herniation is the extrusion of nucleus pulposus through a rent in annulus fibrosus ${ }^{[26]}$. It causes impairment of function by nerve root compression compelling the patient to seek medical advice for low backache. Disc prolapse can generally be resolved with physical therapy and an epidural injection of glucocorticoids or by a surgical intervention ${ }^{[27]}$. Degenerative disc disease is another major finding from lumbosacral MRI scans in this study. It occurs from degenerative changes in the intervertebral disc. Degenerative changes represent a broad category which includes the subcategories of annular fissure, herniation, and degeneration. ${ }^{[28]}$ Degeneration may include any or all of the following: real or apparent desiccation; fibrosis; narrowing of the disc space; diffuse bulging of the annulus beyond the disc space; extensive fissuring (e.g., numerous annular tears), mucinous degeneration of the annulus; and the occurrence of osteophytes at the vertebral endplates ${ }^{[27,28]}$. In relation to findings across gender, we observed that both male and female patients were evenly affected by intervertebral disc prolapse. In this study, 24 females (57.1\%) and 18 males (52.9\%) had normal MRI scans. Females were more affected by basal ganglia edema and intra- 
muscular lipoma ( $n=100 \%)$, while more males suffered from multiple sclerosis and spine metastasis. The relationship between MRI findings and age revealed that $90 \%$ of patients with intervertebral disc prolapse were between the ages of 41 and 60.100 percent of patients with L4-L5 degenerative disc disease were in the 41-50 years of age group, while $71 \%$ of the patients who had normal scans were between 11 and 40 years of age.

\section{CONCLUSION}

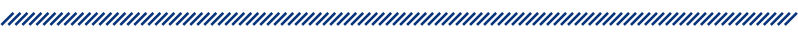

This small-scale feasibility study has identified lumbosacral MRI as the commonest request, while intervertebral disc prolapse was the major finding from MRI scans of patients in Bauchi State, Nigeria. L4-L5 degenerative disc disease was second most prevalent finding, while basal ganglia edema, lipoma, metastases and multiple sclerosis were less common but with equal incidences.

\section{COMPETING INTERESTS}

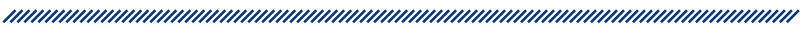

The authors declare that they have no competing interest.

\section{REFERENCES}

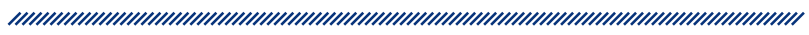

1. Magnetic Resonance Imaging of the Body [Cited 11 May, 2016] Available from: http://www.radiologyinfo.org/en/ info.cfm?pg=bodymr

2. Webberly H, Lam P, Mri scans: how do they work? [Cited 11 May, 2016] Available from: http://www.medicalnewstoday.com/articles/146309.php

3. Tesla Memorial Society of New York, A short History of Magnetic Resonance imaging. [Cited 14 May, 2016] Available from: http://www.teslasociety.com/mri.htm

4. Bushberg JT, Seibert JA, Leidholdt EM, Boon JM., The Essentials of Medical Imaging. 2nd ed. Philadelphia: Lippincott, Williams and Wilkins; 2001. 167-190

5. Carlton RR, Adler AM. Principles of Radiographic Imaging: An Art and a Science. 5th ed. Delmar; 2012. 111-114

6. Griffiths PD, Michael B, Michael JC, Cooper CL, Graham $R$, Jarvis $D$, et al. Use of MRI in the diagnosis of fetal brain abnormalities in utero (MERIDIAN): a multicentre, prospective cohort study. The Lancet 2017; vol 389, Issue 10068, 538 - 546

7. Oikarinen H, Karttunen A, Pääkkö E, Tervonen O. Survey of inappropriate use of magnetic resonance imaging. Insights into Imaging. 2013;4(5):729-733. doi:10.1007/ s13244-013-0276-2.

8. Bekiesińska-Figatowska M. On Unwarranted Performance of MRI Scans. Polish Journal of Radiology. 2014;79:239-242. doi:10.12659/PJR.890225.

9. Mustapha Z, Alhmadu MS, Abba AA, Ibrahim K. and Okedayo M. Patterns of Requests and Findings in Magnetic Resonance Imaging (MRI) of the Lumbosacral Spine at University of Maiduguri Teaching Hospital, Northeastern Nigeria. IOSR Journal of Dental and Medical Sciences (IOSR-JDMS). 2013; e-ISSN: 2279-0853, p-ISSN: 22790861. Volume 11, Issue 4, PP 18-24

10. Uduma FU, Ongolo P, Assam G, Fokam P, Motah M. Evaluation of Pattern of Magnetic Resonance Images of Lumbo-sacral Spine in Cameroon - A Pioneer Study. Global Journal of Medical Research 2011;11;2;30-41.

11. Irurhe NK, Adekola OO, Quadri AR, Menkiti ID, Udenze IC, Awolola NA. The Magnetic Resonance Scan Findings in Adult Nigerian with Low Back Pain. World J Med Sci. 2012; 7 (4): 204-9.

12. Sadro CT and Dubinsky TJ. CT in pregnancy: Risks and benefits. Appl Radiol. 2013. 12-17.

13. Younis F, Shahzad R, Rasool F. "Correlation of Magnetic Resonance Patterns of Lumbar Disc Disease with Clinical Symptomatology of Patients" Annals 2011; 17: Jan - Mar. 9-12

14. Hoy, D., Bain, C., Williams, G., March, L., Brooks, P., Blyth, F., Woolf, A., Vos, T. and Buchbinder, R. A systematic review of the global prevalence of low back pain. Arthritis \& Rheumatism. 2012; 64: 2028-2037. doi:10.1002/art.34347 
15. Roudsari B, Jarvik JG. Lumbar Spine MRI for Low Back Pain: Indications and Yield. AJR 2010; 195:550-559

16. Svensson HO, Andersson GB, Hagstad A, Jansson PO. The relationship of low-back pain to pregnancy and gynecologic factors. Spine 1990; 15: 371-5.

17. Tissot F, Messing K. Perimenstrual symptoms and working conditions among hospital workers in Quebec. Am J Ind Med 1995; 27: 511-2.

18. Smith DR, Mihashi M, Adachi Y, Shouyama Y, Mouri F, Ishibashi N, et al. Menstrual disorders and their influence on low back pain among Japanese nurses. Ind Health 2009; 47: 301-12.

19. Borg-Stein J, Dugan SA. Musculoskeletal disorders of pregnancy, delivery and postpartum. Phys Med Rehabil Clin N Am 2007; 18: 459-76.

20. Han IH. Pregnancy and spinal problems. Curr Opin Obstet Gynecol; 22: 477-81.

21. Wang SM, Dezinno P, Maranets I, Berman MR, CaldwellAndrews AA, Kain ZN. Low back pain during pregnancy: prevalence, risk factors, and outcomes. Obstet Gynecol 2004; 104: 65-70.

22. Royal Australian and New Zealand College of Radiologists (RANZCR). Radiology written report guideline, (short) version 5 (final). Sydney: RANZCR, 2011
23. Ibe MON. Surgially Treated Symptomatic Prolapsed Lumbar and Sacral Intervertebral Discs in Females: A Comparative Study of Incidence and Causative Factors and Treatment. Niger J Surg 2012; 18:61-7

24. Cheung KMC, Karppinen J, Chan D, Ho DWH, Song Y, Sham P, et al. Prevalence and Pattern of Lumbar Magnetic Resonance Imaging Changes in a Population Study of One Thousand Forty-Three Individuals. Spine 2009; 34;9:934-940

25. Buckwalter J. Aging and degeneration of human intervertebral disc. Spine 1995;20:1307-14

26. Prasad P, Hoda M, Dhakal M, Singh K, Srivastava A, Sharma V. Epidemiological Characteristics Of Lumbar Disc Prolapse In A Tertiary Care Hospital The Internet Journal of Neurosurgery. 2005 3(1) 9-13.

27. Schoenfeld AJ, Weiner BK. Treatment of lumbar disc herniation: Evidence-based practice. International Journal of General Medicine. 2010; 3:209-214.

28. Fardon DF, Williams AL, Dohring EJ, Murtagh FR, Gabriel Rothman SL, Sze GK. Lumbar disc nomenclature: version 2.0: Recommendations of the combined task forces of the North American Spine Society, the American Society of Spine Radiology and the American Society of Neuroradiology. Spine J. 2014 Nov 1. 14 (11):2525-45. 
PROCJENA ZAHTJEVA ZA SNIMANJE I NALAZA NA TEMELJU MR SLIKA PACIJENATA U DRŽAVNOJ SPECIJALISTIČKOJ BOLNICI BAUCHI

\author{
1 Prince Ameh Ogenyi \\ 2 Andrew England \\ 1 Joseph Dlama \\ 3 Fati Malgwi \\ 1 Mohammed Umar \\ 3 Moi Silas \\ 4 Samuel Shem \\ 1 Ginikanwa Njoku \\ 1 Odjel radiologije, Sveučilišna bolnica Abubakar Tafawa \\ Balewa, Bauchi, Nigerija. \\ 2 Uprava za radiografiju, Sveučilište u Salfordu, \\ Manchester, Ujedinjeno Kraljevstvo. \\ 3 Uprava za radiografiju, Sveučilište u Maiduguriju, Borno, \\ Nigerija. \\ 4 Odjel radiologije, Državna specijalistička bolnica Gombe, \\ Nigerija.
}

\section{Sažetak}

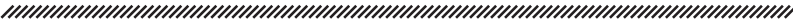

Pozadina: MR snimanje ima važnu ulogu kod dijagnosticiranja bolesti.

Ciljevi: Odrediti obrazac zahtjeva za snimanje i nalaza na temelju MR slika pacijenata u Državnoj bolnici Bauchi.

Metodologija: Prospektivno transverzalno istraživanje obrazaca zahtjeva za MR snimanje i nalaza 138 pacijenata provedeno je od kolovoza 2016. do siječnja 2017. godine. MR slike snimljene su MR skenerom 0.35T Neusoft, a izradila ih je skupina konzultanata radiologa. Podaci su analizirani deskriptivnom statistikom uporabom računalnog programa SPSS, verzija 22 (IBM, New York, SAD).
Rezultati: Ovo istraživanje pokazalo je da se većina zahtjeva za MR snimanje odnosila na preglede lumbosakralne kralješnice ( $n=84,60,9 \%$ ), nakon čega slijedi MR mozga ( $n=42,30,4 \%$ ), a zatim pregledi ramena $\mathrm{i}$ abdomena (po 4,3 \% za obje vrste). Od 138 snimljenih MR slika, najčešći nalaz na temelju MR snimanja pacijenata bio je prolaps intervertebralnog diska ( $n=60,43,5 \%$ ), dok je drugi najčešći nalaz bio degenerativna bolest diska L4-L5 ( $n=12,8,7 \%$ ). Intramuskularni lipom i edem bazalnih ganglija imaju prevalenciju od 4,3\%.

Zaključak: Najčešći zahtjevi odnosili su se na MR snimanje lumbosakralne kralješnice, dok su prolaps intervertebralnog diska, degenerativna bolest diska L4-L5, edem bazalnih ganglija i intramuskularni lipom glavni nalazi na temelju MR snimanja u Bauchiju.

Ključne riječi: bazalni gangliji, prolaps diska, metastaza, lipom 